Jurnal Pembangunan Sosial 9 (Jun) 2006: 61-84

\title{
Faktor yang Mempengaruhi Kesetiaan Terhadap Organisasi di Kalangan Penjawat Awam
}

\author{
KHULIDA KIRANA YAHYA \\ JOHANIM JOHARI \\ ZURINA ADNAN \\ MOHD FAIZAL MOHD ISA \\ ZULKIFLEE DAUD
}

\begin{abstract}
This study was conducted to identify factors influencing loyalty towards organization among exempt and non-exempt employees in the government sector. Factors examined are management support, career development, job security, training and development, and compensation. Data collected through self-administered questionnaires, whereby 356 sets were distributed and 349 sets $(98.03 \%)$ were analyzed. Pearson Correlation and Multiple Regression analyses were used to analyze the data. Findings indicate that all factors examined have positive correlation with the loyalty among employees. Regression analysis showed that management support, job security, and training and development have influenced on the level of loyalty among employees towards organization. Therefore, it is crucial for the top management to take into account these factors in improving loyalty among employees.
\end{abstract}

\begin{abstract}
ABSTRAK
Kajian ini dijalankan untuk mengenalpasti faktor yang mempengaruhi kesetiaan di kalangan pekerja peringkat sokongan dan pengurusan di sebuah badan kerajaan. Faktor yang dikaji adalah sokongan pengurusan, pembangunan kerjaya, jaminan pekerjaan, latihan dan pembangunan, dan ganjaran. Pengumpulan data dilakukan melalui kaedah soal selidik. Sebanyak 356 set soal selidik diedarkan dan hanya 349 (98.03\%) set soal selidik digunakan untuk tujuan penganalisisan. Data dianalisis menggunakan ujian korelasi Pearson dan ujian regresi berganda. Hasil kajian mendapati semua faktor yang dikaji mempunyai hubungan yang positif dengan kesetiaan pekerja terhadap organisasi. Analisis regresi pula menunjukkan hanya dimensi sokongan pengurusan, jaminan pekerjaan, serta latihan dan pembangunan, mempunyai pengaruh perkaitan yang signifikan dengan dimensi kesetiaan. Oleh itu adalah penting bagi pihak majikan memberi perhatian terhadap aspek berikut dalam meningkatkan tahap kesetiaan pekerja terhadap organisasi.
\end{abstract}




\title{
REKABENTUK KAJIAN
}

Pembolehubah bersandar bagi kajian ini adalah kesetiaan terhadap organisasi, manakala pembolehubah tidak bersandar adalah sokongan pengurusan, pembangunan kerjaya, jaminan pekerjaan, latihan dan pembangunan, serta ganjaran (Rajah 1)

\author{
Sokongan Pengurusan \\ Pembangunan Kerjaya \\ KESETIAAN \\ - Nilai Persamaan \\ - Taat Setia \\ - Dipunyai
}

Latihan dan Pembangunan

Jaminan Pekerjaan

Ganjaran

\section{Rajah 1}

Hubungan di antara faktor-faktor yang mempengaruhi kesetiaan terhadap organisasi

\section{TINJAUAN LITERATUR}

\section{Kesetiaan}

Menurut Chen (2001), kesetiaan merujuk kepada dedikasi seseorang pekerja kepada organisasi dan identifikasi dengan organisasi iaitu perasaan bangga menjadi pekerja organisasi tersebut. Kesetiaan terbahagi kepada tiga iaitu nilai persamaan, taat setia, dan dipunyai (King \& Ehrhard, 1997). Nilai persamaan merujuk darjah persamaan nilai di dalam diri seseorang dengan nilai organisasi. Apabila seseorang merasakan nilai dalam dirinya sama dengan nilai yang dipegang oleh organisasi, seseorang itu dikatakan mempunyai nilai persamaan yang tinggi dengan organisasi tersebut. Ini akan mengeratkan hubungan dan mewujudkan suasana kerja yang harmoni dalam organisasi. Taat 


\section{PENGENALAN}

Pengekalan pekerja merujuk kepada komitmen seseorang untuk terus kekal di dalam organisasi dan pengekalan ini wujud kerana sifat puas hati dan percaya kepada organisasi tersebut (Hansemark \& Albinsson, 2004). Sesetengah organisasi mungkin mendapat faedah daripada perpindahan pekerja ke organisasi lain, tetapi kadar lantik-henti yang tidak terkawal boleh meningkatkan kos perekrutan, pemilihan, dan latihan. Walaupun tindakan pekerja meninggalkan organisasi adalah di luar kawalan majikan, beberapa langkah proaktif boleh diambil oleh majikan untuk menjamin kesetiaan pekerja terhadap organisasi tersebut. Pertama, secara praktikalnya, kos dapat dikurangkan jika individu yang telah direkrut, dipilih, dan dilatih dapat dikekalkan untuk tempoh masa yang panjang. Kedua, prestasi organisasi dan individu juga mampu ditingkatkan kerana individu yang terus setia bekerja dengan organisasi akan lebih mengetahui tentang tugas dan tangg ungjawab, rak n sekerja, perkhidmatan atau produk organisasi serta pelanggan mereka. Yang terakhir, pekerja yang setia, mampu memberi imej yang positif kepada majikan dan organisasi. Hal ini boleh menarik pekerja baru dan mengekalkan pekerja yang sedia ada (Hansemark \& Albinsson, 2004).

Berdasarkan tinjauan yang ditakukan oleh Society for Human Resource Management pada tahun 2000, antara sebab utama pekerja meninggalkan organisasi (menurut turutan yang tertinggi ke terendah) termasuklah peluang kerjaya di tempat lain, pakej pampasan yang lebih menarik, pengurusan yang lemah, kesukaran pasangan untuk berpindah, kembali belajar, persaraan, risau akan keselamatan pekerjaan, hubungan yang kurang baik dengan rakan sekerja, isu-isu yang berkaitan dengan penjagaan anak-anak, persepsi yang berkaitan dengan diskriminasi dan sebab-sebab yang berkaitan dengan kesihatan (Mathis \& Jackson, 2004).

Berdasarkan kepada hasil tinjauan tersebut, organisasi boleh mengambil beberapa pendekatan bagi mengekalkan pekerja. Ini termasuklah menerangkan secara realistik akan pekerjaan yang ditawarkan kepada pemohon semasa proses perekrutan, memastikan pemohon dipadankan dengan jawatan yang sesuai, memastikan pampasan yang dibayar adalah kompetitif, adil dan setara, membuat perancangan dan pembangunan kerjaya yang dapat membantu organisasi mengekalkan pekerja, dan memberi layanan yang adil serta tidak melakukan diskriminasi terhadap pekerja (Mathis \& Jackson, 2004). Oleh itu, objektif kajian ini adalah untuk mengenalpasti amalan pengurusan sumber manusia yang mempengaruhi tahap kesetiaan pekerja terhadap organisasi. Faktor yang dikaji adalah sokongan pengurusan, pembangunan kerjaya, jaminan pekerjaan, latihan dan pembangunan, serta ganjaran. 
individu mendapatkan kemahiran dan pengalaman bagi menjayakan pekerjaan masa kini dan hadapan. Dengan adanya program pembangunan kerjaya, pekerja dapat mengenalpasti minat serta kekuatan diri mereka di samping merancang kerjaya yang ingin mereka capai. Harris, Hirshfeld, Field dan Mossholder (1993) menjelaskan pembangunan kerjaya adalah proses spesifik yang boleh membantu pekerja mencapai matlamat diri dan organisasi menerusi maklumat kerjaya yang lengkap dan peluang kerjaya yang tidak terhad. Kedua-dua aspek ini akan meningkatkan produktiviti dan kepuasan pekerja.

Selain itu, program pembangunan kerjaya yang berkesan melibatkan sokongan daripada pengurus lini dan pengurus atasan. Selain itu, para pekerja perlu tahu peranan mereka dalam pembangunan kerjaya dengan mengambil beberapa langkah penting seperti mendapat maklum balas tentang prestasi kerja daripada penyelia, mengenalpasti keperluan pembangunan bagi jawatan yang berkenaan, dan menggunakan peluang sebaik mungkin untuk meningkatkan pengetahuan, kemahiran, dan kebolehan (Harris et al., 1993).

\section{Jaminan Pekerjaan}

Jaminan pekerjaan merujuk kepada sejauh mana sesebuah organisasi menyediakan pekerjaan yang stabil untuk pekerjanya (Burke, 1997). Pekerja akan kekal dalam sesebuah organisasi sekiranya hak mereka seperti gaji, pencen, kekananan, dan sebagainya tidak dikurangkan dengan sewenang-wenangnya oleh pihak majikan (Meltz, 1989). Kajian oleh Leana dan Feldman (1992), Burke (1997), dan Yousef (1997) mendapati pekerja yang berpuas hati dengan jaminan pekerjaan menunjukkan tahap komitmen yang lebih tinggi dan keinginan untuk berhenti yang rendah. Yousef (1997) pula menambah semakin meningkat umur, jawatan, dan pendapatan seseorang pekerja itu semakin mereka berpuas hati dengan jaminan pekerjaan masing-masing. Selain itu prestasi pekerja adalah lebih baik jika mereka mempunyai pekerjaan yang stabil (Yousef, 1997).

\section{Latihan dan Pembangunan}

Latihan dan pembangunan merupakan suatu program untuk meningkat pengetahuan, kemahiran dan kebolehan pekerja supaya dapat melaksanakan tanggungjawab sekarang dan akan datang dengan lebih berkesan (Desimone et al. 2002). Latihan dan pembangunan juga penting untuk pembangunan dan pencapaian matlamat organisasi. Kajian oleh Lam dan Qiu Zhang (2003) menunjukkan bahawa latihan dan pembangunan merupakan faktor utama mempengaruhi komitmen dan kepuasan pekerja terhadap tugas dan tanggungjawab mereka. Dapatan ini menjelaskan bahawa program latihan dan pembangunan yang berterusan membantu pekerja membangunkan kemahiran yang diperlukan. Dengan itu, mereka boleh melaksanakan tugas tanpa perlu bergantung kepada orang lain. Ini akan mempengaruhi tahap pengekalan pekerja dalam organisasi (Lam \& Qiu Zhang, 2003). Walau bagaimanapun, Acton dan 
setia merupakan satu perasaan taat yang ditunjukkan oleh seseorang pekerja terhadap organisasi. Dipunyai atau rasa dipunyai merupakan satu perasaan yang menunjukkan seseorang itu adalah hak kepada organisasinya. Kajian oleh Becker et al. (1996), Chen (2001) dan Gregersen (1993) menunjukkan kesetiaan, dan bukannya komitmen, merupakan peramal utama dalam menentukan prestasi pekerja dan sikap kewarganegaraan organisasi. Internalization didefinisikan oleh Chen (2001) sebagai persamaan nilai di antara organisasi dan pekerja. Persamaan di antara nilai yang ditunjukkan oleh majikan dan nilai yang diutamakan oleh pekerja mempengaruhi sikap pekerja di tempat kerja berbanding faktor lain (Chen, 2001).

\section{Sokongan Pengurusan}

Sokongan pengurusan merujuk kepada kemahiran kepimpinan pihak pengurusan. Kepimpinan adalah kebolehan untuk mempengaruhi kumpulan pekerja dalam pencapaian matlamat. Terdapat dua sumber kepimpinan, iaitu secara formal yang berdasarkan kedudukan dalam struktur organisasi atau secara tidak formal iaitu seseorang yang dilantik menjadi ketua oleh ahli kumpulan. Menurut Robbins (2001) ciri-ciri yang perlu ada pada seorang ketua adalah seperti berikut :

1. Berkuasa dan bermatlamat

2. Berkeinginan menjadi ketua

3. Bersikap jujur dan mempunyai integriti

4. Berkeyakinan diri

5. Cerdik

6. Berpengetahuan berkenaan tugas

Fiedler (1967) telah membina model kontingensi yang menjelaskan bahawa keberkesanan sesebuah kumpulan bergantung kepada kesesuaian gaya kepimpinan ketua semasa berinteraksi dengan ahli kumpulan atau pekerja (Robbins, 2001). Fiedler juga percaya bahawa kejayaan seseorang ketua bergantung kepada gaya kepimpinannya (Robbins, 2001). Oleh kerana itu, beliau telah mengenalpasti tiga faktor persekitaran yang mempengaruhi keberkesanan kepimpinan, iaitu hubungan ketua dan ahli, struktur tugas, dan kedudukan kuasa.

\section{Pembangunan Kerjaya}

Pembangunan kerjaya merupakan satu proses berterusan yang melibatkan pergerakan individu melalui peringkat kehidupan yang mempunyai isu, tema, dan tugas yang tersendiri (Desimone et al. 2002). Menurut Mondy dan Noe (2001), kerjaya adalah pekerjaan yang dipilih oleh individu sepanjang kehidupannya. Namun ia pasti akan berubah disebabkan perubahan teknologi serta keinginan individu untuk melakukan sesuatu yang berbeza. Pembangunan kerjaya juga merupakan pendekatan formal yang digunakan oleh organisasi untuk membantu 
tahap komitmen dan pengekalan pekerja.

\section{METOD KAJIAN}

\section{Populasi dan Sampel}

Kajian ini menggunakan kaedah persampelan mudah (convenience sampling) dan ia dijalankan melalui pengedaran borang soal selidik kepada para responden. Terdapat seramai 2900 pekerja di jabatan berkenaan, tetapi seramai 356 orang pekerja sahaja digunakan sebagai sampel kajian. Menurut Sekaran , saiz sampel ini mencukupi berdasarkan model keputusan persampelan yang baik seperti yang dinyatakan oleh Krejcie dan Morgan (Sekaran, 2003).

\section{Ujian Rintis}

Ujian rintis dijalankan bagi menguji tahap kebolehpercayaan dan kefahaman terhadap soalan dan struktur ayat dalam borang soal selidik yang diedarkan. Sebanyak 17 set soal selidik telah diedarkan kepada responden dengan peratus kutipan 100 peratus. Keputusan daripada ujian kebolehpercayaan menunjukkan soalan berkaitan sokongan pengurusan, pembangunan kerjaya, jaminan pekerjaan, latihan dan pembangunan, dan ganjaran memberikan nilai Alpha Cronbach yang tinggi iaitu melebihi 0.5 .

\section{Pembentukan Borang Soal Selidik dan Pengumpulan Data}

Soal selidik penting bagi tujuan pengumpulan data. Pembentukan soal selidik yang baik dapat membantu mendapatkan hasil kajian yang memuaskan. Pembentukan item soal selidik terbahagi kepada dua iaitu pembolehubah tidak bersandar (sokongan pengurusan, pembangunan kerjaya, latihan dan pembangunan, ganjaran, serta jaminan pekerjaan) dan pembolehubah bersandar iaitu kesetiaan (nilai persamaan, taat setia, dan dipunyai). Soalan bagi item soal selidik untuk setiap pembolehubah adalah seperti di Jadual 1.

Jadual 1 ini memaparkan definisi bagi operasi dan item bagi setiap pemboleh ubah tidak bersandar. Bagi setiap penyataan item terdapat lima pilihan jawapan yang boleh dipilih oleh responden kajian. Pilihan jawapan tersebut menggunakan skala Likert 5 mata, di mana skala Likert 1 mewakili 'sangat tidak setuju', 2 'tidak setuju', 3 'tidak pasti', 4 'setuju' dan 5 'sangat setuju'.

Jadual 2 memaparkan definisi operasi dan item bagi setiap pembolehubah bersandar (kesetiaan). Pilihan jawapan bagi setiap item menggunakan skala Likert 5 mata iaitu 1 mewakili 'amat puas hati, 2 'tidak puas hati', 3 'tidak pasti', 4 'puas hati' dan 5 'amat puas hati'. 
Golden (2003) mendapati latihan dan pembangunan tidak mempengaruhi pengekalan pekerja. Ini adalah kerana pekerja menganggap latihan adalah penting untuk pembangunan kerjaya, tetapi bukan sebagai faktor utama yang mempengaruhi keputusan mereka untuk terus kekal dalam pekerjaan atau organisasi yang sama.

\section{Ganjaran}

Ganjaran merujuk kepada apa yang diterima oleh pekerja berdasarkan prestasi kerja (Solomon, 1998). Ganjaran berfungsi dalam mengekal dan memotivasikan pekerja (Milkovich \& Newman, 2002; Henderson, 2000). Bagaimanapun Carciner et al. (2004) mendapati ganjaran bukan merupakan faktor penentu dalam mengekalkan pekerja. Ini kerana persepsi terhadap keadilan dalam pemberian ganjaran adalah lebih penting dalam mempengaruhi hasrat untuk berhenti dan kadar lantik-henti (Carciner et al. 2004). Dapatan kajian oleh Carciner et al. (2004) ini selari dengan kajian oleh Ferris et al. (1996) yang mendapati persepsi pekerja terhadap keadilan dalam pembahagian sumber mempengaruhi kepuasan kerja dan hasrat untuk berhenti. Walau bagaimanapun, kajian perbandingan ganjaran di Hong Kong dan China oleh Chiu et al. (2002) pula mendapati lima jenis ganjaran yang penting dalam mengekalkan pekerja adalah gaji asas, bayaran merit, bonus hujung tahun, cuti tahunan, dan kemudahan pinjaman dengan kadar bunga yang rendah. Chiu et al. (2002) menjelaskan lima jenis ganjaran yang penting dalam memotivasikan pekerja adalah gaji asas, bayaran merit, bonus hujung tahun, perkongsian laba, dan cuti tahunan. Ini jelas menunjukkan bahawa ganjaran kewangan amat diutamakan oleh para pekerja untuk mengekal dan memotivasikan mereka. Chiu et al. (2002) juga mendapati faktor geografi, ekonomi, dan budaya mempengaruhi pengekalan dan motivasi pekerja. Henderson (2000) menjelaskan bahawa setiap majikan perlu membina satu struktur gaji yang adil. Ini adalah kerana pekerja gemar membandingkan upah yang diterima dengan pekerja lain dalam organisasi yang sama atau pekerja di organisasi lain yang melakukan tugas yang sama. Perbezaan yang ketara tanpa justifikasi yang jelas pasti akan mempengaruhi

\section{Jadual 1}

Definisi Operasi dan Item bagi Pembolehubah Tidak Bersandar

\begin{tabular}{|c|c|c|}
\hline Pembolehubah & $\begin{array}{l}\text { Definisi operasi setiap } \\
\text { faktor }\end{array}$ & Item \\
\hline Latihan berterusan & $\begin{array}{l}\text { Galakkan dan peluang } \\
\text { yang diberikan kepada } \\
\text { pekerja agar dapat } \\
\text { meningkatkan } \\
\text { pengetahuan dan } \\
\text { kemahiran. }\end{array}$ & $\begin{array}{l}\text { - Saya digalakkan untuk menghadiri program } \\
\text { latihan. } \\
\text { - Program latihan yang saya perlu ditentukan oleh } \\
\text { ketua saya. } \\
\text { - Saya diberi peluang untuk meningkatkan } \\
\text { pengetahuan dan kemahiran serta memperbaiki } \\
\text { prestasi kerja melalui latihan. } \\
\text { - Saya diberi latihan agar dapat melakukan tugas } \\
\text { dengan baik. } \\
\text { - Saya diberi peluang untuk menyertai tugas-tugas } \\
\text { yang boleh membantu kenaikan pangkat saya. } \\
\text { (Sumber : Desimone, Werner \& Harris, 2002) }\end{array}$ \\
\hline
\end{tabular}


(sambungan Jadual 1)

\begin{tabular}{|c|c|c|}
\hline $\begin{array}{l}\text { Pembangunan } \\
\text { kerjaya }\end{array}$ & $\begin{array}{l}\text { Pemberian peluang untuk } \\
\text { mendapatkan maklumat } \\
\text { tentang kerjaya, kenaikan } \\
\text { pangkat dan memajukan } \\
\text { diri dengan adil. }\end{array}$ & $\begin{array}{l}\text { - Saya boleh mendapatkan maklumat mengenai } \\
\text { perancangan kerjaya saya. } \\
\text { - Saya dan ketua sering berbincang mengenai } \\
\text { peluang pembangunan kerjaya saya. } \\
\text { - Saya diberi peluang secukupnya untuk kenaikan } \\
\text { pangkat. } \\
\text { - Saya diberi peluang secukupnya untuk memajukan } \\
\text { diri dalam kerjaya saya. } \\
\text { - Saya berpuas hati dengan amalan kenaikan } \\
\text { pangkat dalam organisasi ini. } \\
\text { - Saya berpuas hati dengan peluang kenaikan } \\
\text { pangkat dalam organisasi ini. } \\
\text { - Kenaikan pangkat diberi berdasarkan merit dalam } \\
\text { prestasi. } \\
\text { - Kenaikan pangkat diberi secara adil dalam } \\
\text { organisasi. } \\
\text { (Sumber : Harris et al., 1995) }\end{array}$ \\
\hline Jaminan pekerjaan & $\begin{array}{l}\text { Jaminan masa depan } \\
\text { yang stabil tanpa } \\
\text { mengalami kesulitan dan } \\
\text { pemberhentian. }\end{array}$ & $\begin{array}{l}\text { - Saya tidak akan mengalami kesulitan dalam } \\
\text { melaksanakan tugas di masa depan. } \\
\text { - Saya tidak akan diberhentikan oleh organisasi ini. } \\
\text { - Tugas saya memberi jaminan masa depan. } \\
\text { - Tugas saya stabil. } \\
\text { (Sumber : Price, 2001). }\end{array}$ \\
\hline $\begin{array}{l}\text { Sokongan } \\
\text { Pengurusan dan } \\
\text { organisasi }\end{array}$ & $\begin{array}{l}\text { Penghargaan dan sikap } \\
\text { ambil berat pengurusan } \\
\text { dan organisasi terhadap } \\
\text { pekerja. }\end{array}$ & $\begin{array}{l}\text { - Organisasi ini menghargai sumbangan saya. } \\
\text { - Organisasi ini gagal menghargai usaha saya. } \\
\text { - Organisasi ini kurang mengambil berat tentang } \\
\text { diri saya. } \\
\text { - Pegawai atasan mengambil berat tentang kepuasan } \\
\text { kerja saya. } \\
\text { - Organisasi ini benar-benar mengambil berat } \\
\text { tentang kesejahteraan hidup saya. } \\
\text { - Pegawai atasan mengambil berat tentang nilai dan } \\
\text { matlamat kerja saya. } \\
\text { - Pegawai atasan berbangga dengan pencapaian } \\
\text { kerja saya. } \\
\text { - Pegawai atasan akan memberi bantuan jika saya } \\
\text { (Sumber : Bishop, Goldsby \& Neck, 2002) }\end{array}$ \\
\hline Ganjaran & $\begin{array}{l}\text { Pemberian gaji, ganjaran } \\
\text { dan penghargaan yang } \\
\text { memuaskan serta } \\
\text { setimpal dengan tugas } \\
\text { yang dilakukan. }\end{array}$ & $\begin{array}{l}\text { - Gaji yang saya terima menggalakkan saya bekerja } \\
\text { dengan lebih rajin. } \\
\text { - Insentif pekerjaan (bonus) menggalakkan saya } \\
\text { melakukan tugas dengan baik. } \\
\text { - Saya diberi penghargaan jika pencapaian kerja } \\
\text { saya baik. } \\
\text { - Saya menerima gaji yang setimpal dengan tugas } \\
\text { yang saya dilakukan. } \\
\text { - Saya berpuas hati dengan gaji yang saya terima. } \\
\text { - Ganjaran (gaji, penghargaan, cuti, elaun) yang } \\
\text { saya terima setimpal dengan usaha yang saya } \\
\text { berikan. } \\
\text { (Sumber: Kim, Price, Mueller \& Watson, 1996). }\end{array}$ \\
\hline
\end{tabular}

\section{Penganalisisan Data}

Data dikumpul melalui borang soal selidik yang diedarkan kepada responden dalam satu sesi yang telah ditetapkan. Para responden diberi masa yang secukupnya untuk memberi jawapan terhadap soalan-soalan yang terdapat dalam borang soal selidik tersebut. Data yang diperolehi dianalisis menggunakan 
Jadual 2

Definisi Operasi dan Item bagi Pembolehubah Bersandar (kesetiaan kepada organisasi)

\begin{tabular}{|c|c|c|}
\hline Pembolehubah & $\begin{array}{l}\text { Definisi operasi setiap } \\
\text { faktor }\end{array}$ & Item \\
\hline $\begin{array}{l}\text { - Nilai } \\
\text { Persamaan }\end{array}$ & $\begin{array}{l}\text { Nilai yang sama di antara } \\
\text { organisasi dan pekerja. }\end{array}$ & $\begin{array}{l}\text { - Untuk memastikan organisasi ini lebih berjaya, } \\
\text { saya sanggup berusaha gigih melebihi apa yang } \\
\text { diharapkan oleh organisasi. } \\
\text { - Saya memberitahu kawan-kawan bahawa } \\
\text { organisasi ini adalah tempat yang baik untuk } \\
\text { bekerja. } \\
\text { - Untuk terus bekerja dalam organisasi ini, saya } \\
\text { akan menerima hampir semua jenis tugas yang } \\
\text { diberikan. } \\
\text { - Kesetiaan yang tinggi kepada kawan-kawan dan } \\
\text { keluarga merupakan kewajipan terpenting bagi } \\
\text { setiap individu. } \\
\text { - Nilai yang ada pada diri saya sama dengan nilai } \\
\text { organisasi. } \\
\text { - Seseorang itu harus sanggup berkorban untuk } \\
\text { kepentingan kawan-kawan dan keluarga. } \\
\text { Kesetiaan yang tinggi kepada negara merupakan } \\
\text { kewajipan terpenting bagi setiap individu. } \\
\text { - Saya bersetuju dengan cara organisasi ini } \\
\text { berurusan dengan orang luar. } \\
\text { (Sumber: King \& Ehrhard, 1997). }\end{array}$ \\
\hline - Taat Setia & $\begin{array}{l}\text { Kesetiaan kepada } \\
\text { negara, kawan-kawan } \\
\text { dan keluarga. }\end{array}$ & $\begin{array}{l}\text { - Organisasi ini menggunakan pengetahuan, } \\
\text { kemahiran, dan keupayaan yang ada pada diri saya } \\
\text { untuk melaksanakan tugas. } \\
\text { - Saya berbangga dengan cara organisasi ini } \\
\text { mengambil berat tentang keselamatan dan kualiti } \\
\text { perkhidmatan yang diberikan. } \\
\text { - Semua pekerja tanpa mengambilkira bangsa, } \\
\text { keturunan, agama, dan fahaman politik seharusnya } \\
\text { menyokong dasarkerajaan tanpa curiga. } \\
\text { - Pekerja harus membuat pengorbanan peribadi } \\
\text { untuk memenuhi keperluan organisasi, seperti } \\
\text { membatalkan atau menangguhkan percutian untuk } \\
\text { menyiapkan tugas pada masa yang ditetapkan. } \\
\text { - Saya berpuashati dengan organisasi ini kerana } \\
\text { menyediakan persekitaran kerja yang selamat dan } \\
\text { selesa. } \\
\text { - Semasa saya mula bekerja di organisasi ini, saya } \\
\text { berasa sungguh gembira kerana telah memilih } \\
\text { organisasi ini berbanding organisasi lain. } \\
\text { - Saya mengambil berat tentang masa depan } \\
\text { organisasi ini. } \\
\text { Kesetiaan yang tinggi kepada organisasi } \\
\text { merupakan kewajipan terpenting bagi setiap } \\
\text { individu. } \\
\text { (Sumber: King \& Ehrhard, 1997). }\end{array}$ \\
\hline - Dipunyai & $\begin{array}{l}\text { Perasaan bangga, rasa } \\
\text { dipunyai dan } \\
\text { mengabdikan diri untuk } \\
\text { melaksanakan tugas yang } \\
\text { diberikan. }\end{array}$ & $\begin{array}{l}\text { - Saya mengagumi kejujuran organisasi ini dalam } \\
\text { berurusan dengan para pekerja dan orang awam. } \\
\text { - Saya berbangga dengan keprihatinan organisasi ini } \\
\text { terhadap keadaan alam sekitar. } \\
\text { - Organisasi ini menghormati dan melindungi hak } \\
\text { dan maruah semua pekerja. }\end{array}$ \\
\hline
\end{tabular}


(sambungan Jadual 2)

\begin{tabular}{|l|l|l|}
\hline \multirow{1}{|l|}{} & $\begin{array}{l}\text { Bagi saya, organisasi ini adalah yang terbaik untuk } \\
\text { bekerja. } \\
\text { Organisasi ini adil dan saya tidak perlu meminta } \\
\text { apa-apa lagi. }\end{array}$ \\
$\begin{array}{l}\text { Pekerja seharusnya sanggup berkorban apa saja } \\
\text { untuk organisasi. } \\
\text { (Sumber : King \& Ehrhard, 1997). }\end{array}$ \\
\hline
\end{tabular}

4.05 peratus dengan empat item soalan berkaitan peluang latihan dan pembangunan di organisasi. Nilai Eigen bagi aspek ini adalah 1.30.

5. Ganjaran dengan nilai keseluruhan varians 22.82 peratus dan mempunyai lima item soalan yang menerangkan peratusan bagaimana gaji mempengaruhi pekerja dalam melaksanakan tugas serta peratusan gaji yang setimpal diterima. Manakala nilai Eigen bagi ganjaran adalah 3.66.

Selain itu, nilai Kaiser-Mayer Olkin (KMO) bagi semua pembolehubah tidak bersandar adalah 0.89. Keputusan analisis faktor yang dilakukan ke atas semua pembolehubah tidak bersandar boleh dilihat dalam Jadual 3.

Keputusan analisis faktor yang dilakukan ke atas pembolehubah bersandar iaitu dimensi kesetiaan kepada organisasi adalah seperti berikut:

1. Faktor nilai persamaan dengan jumlah keseluruhan varians 9.02 peratus yang terdiri daripada lima item soalan yang berkaitan perasaan dan kesetiaan pekerja terhadap organisasi.

2. Faktor taat setia dengan nilai keseluruhan varians sebanyak 7.65 peratus mempunyai tiga item soalan yang menerangkan mengenai perasaan dan kesetiaan pekerja terhadap kawan-kawan dan keluarga.

3. Faktor dipunyai dengan nilai keseluruhan varians sebanyak 5.44 peratus. Faktor ini mempunyai tiga item soalan berkaitan peratusan kesetiaan pekerja terhadap organisasi ini berbanding organisasi lain.

Nilai Eigen bagi setiap faktor di bawah aspek kesetiaan adalah 1.89 (nilai persamaan), 1.61 (taat setia), dan 1.14 (dipunyai). Manakala nilai Kaiser-Mayer Olkin (KMO) bagi aspek kesetiaan adalah 0.877. Keputusan analisis faktor yang dilakukan ke atas pembolehubah bersandar (dimensi kesetiaan kepada organisasi) boleh dilihat dalam Jadual 4.

\section{Jadual 4}

Keputusan Analisis Faktor bagi Pembolehubah Bersandar (kesetiaan kepada organisasi) Ujian Kebolehpercayaan

Selepas analisis faktor dijalankan, ujian kebolehpercayaan (Alpha Cronbach) dilakukan bagi melihat tahap kepercayaan item soalan. Jadual 5 menunjukkan 
perisian komputer SPSS (Statistical Package for Social Sciences). Data dianalisis menggunakan statistik frekuensi, purata, sisihan piawai, faktor analisis, dan korelasi. Penganalisisan data bermula dengan analisis faktor terhadap soalan-soalan berbentuk skala Likert dalam borang soal selidik. Analisis faktor merupakan satu kaedah yang digunakan untuk membahagikan faktor-faktor dalam setiap pembolehubah kajian. Kaedah ini dilakukan melalui kaedah pengasingan data berdasarkan soalan-soalan dalam soal selidik. Ukuran Kaiser-Meyer Olkin (KMO) juga digunakan untuk melihat peratus kecukupan persampelan yang digunakan. Ujian kebolehpercayaan dilakukan dengan menggunakan Alpha Cronbach untuk mengukur kebolehpercayaan soalansoalan yang telah diasingkan melalui analisis faktor. Analisis korelasi pearson dilakukan untuk mengenalpasti hubungan di antara pembolehubah bersandar dengan pembolehubah tidak bersandar. Manakala analisis regresi berganda digunakan untuk mengenal pasti pengaruh pembolehubah tidak bersandar ke atas pembolehubah bersandar.

\section{Analisis Faktor}

Bahagian ini menerangkan tentang keputusan Principal Component Analysis yang dilakukan ke atas semua pembolehubah bersandar dan pembolehubah tidak bersandar. Kaedah putaran berdasarkan varians maksimum (Varimax) digunakan bagi memudahkan struktur faktor yang terbentuk ditafsirkan. Objektif utama putaran varians maksimum ialah mengumpulkan item-item yang berkaitan di bawah satu faktor. Struktur ini membolehkan setiap faktor mewakili satu nilai yang berbeza, dan bersifat tersendiri. Daripada kaedah ini, item yang mempunyai dua nilai yang sama akan digugurkan.

Keputusan analisis faktor yang dilakukan ke atas semua pembolehubah tidak bersandar adalah seperti berikut:

1. Sokongan pengurusan dengan jumlah keseluruhan varians ialah 26.78 peratus mengandungi enam item soalan yang menerangkan peratusan bagaimana pihak pengurusan memberikan sokongan kepada pekerja seperti menghargai sumbangan pekerja, mengambil berat tentang kepuasan kerja dan kesejahteraan hidup pekerja serta memberi tunjuk ajar kepada pekerja. Nilai Eigen bagi sokongan pengurusan adalah 8.57.

2. Jaminan pekerjaan dengan jumlah keseluruhan varians ialah 6.51 peratus mengandungi tiga item soalan yang berkaitan tugas yang stabil dan menjamin masa depan. Nilai Eigen bagi jaminan pekerjaan adalah 2.08.

3. Pembangunan kerjaya dengan jumlah keseluruhan varians 5.70 peratus menerangkan peratusan peluang yang diberikan kepada pekerja untuk memajukan diri, mendapat kenaikan pangkat serta memperolehi maklumat tentang kerjaya. Faktor ini mempunyai empat item soalan dan mempunyai nilai Eigen sebanyak 1.82.

4. Latihan dan pembangunan yang mempunyai nilai keseluruhan varians 
Jadual 3

Keputusan Analisis Faktor bagi Pembolehubah Tidak Bersandar (sokongan pengurusan, jaminan pekerjaan, pembangunan kerjaya, latihan dan pembangunan, serta ganjaran)

\begin{tabular}{|c|c|c|c|c|c|}
\hline Item & Faktor 1 & $\begin{array}{c}\text { Faktor } \\
2\end{array}$ & Faktor 3 & Faktor 4 & Faktor 5 \\
\hline $\begin{array}{l}\text { Sokongan Pengurusan } \\
\text { - } \quad \text { Organisasi menghargai sumbangan. } \\
\text { Pegawai mengambil berat tentang } \\
\text { kepuasan kerja } \\
\text { Organisasi mengambil berat tentang } \\
\text { kesejahteraan hidup } \\
\text { Pegawai mengambil berat tentang nilai } \\
\text { dan matlamat kerja. } \\
\text { Pegawai berbangga dengan pencapaian } \\
\text { kerja } \\
\text { Pegawai memberi bantuan jika } \\
\text { menghadapi masalah dalam tugas. }\end{array}$ & $\begin{array}{l}0.460 \\
0.699 \\
0.759 \\
0.761 \\
0.714 \\
0.591\end{array}$ & & & & \\
\hline $\begin{array}{l}\text { Jaminan Pekerjaan } \\
\text { - Nilai yang ada dalam diri adalah selari } \\
\text { - dengan misi organisasi } \\
\text { - Tugas memberi jaminan masa depan. } \\
\text { Tugas stabil. }\end{array}$ & & $\begin{array}{l}0.586 \\
0.682 \\
0.657\end{array}$ & & & \\
\hline $\begin{array}{l}\text { Pembangunan Kerjaya } \\
\text { - Mendapatkan maklumat mengenai } \\
\text { perancangan kerjaya. } \\
\text { Berbincang mengenai peluang } \\
\text { pembangunan kerjaya. } \\
\text { Diberi peluang secukupnya untuk } \\
\text { kenaikan pangkat. } \\
\text { Diberi peluang secukupnya untuk } \\
\text { memajukan diri dalam kerjaya. } \\
\end{array}$ & & & & $\begin{array}{l}0.624 \\
0.682 \\
0.781 \\
0.682\end{array}$ & \\
\hline $\begin{array}{l}\text { Latihan dan Pembangunan } \\
\text { - Digalakkan menghadiri program latihan } \\
\text { - Memperbaiki prestasi kerja melalui } \\
\text { latihan. } \\
\text { Diberi latihan agar dapat melakukan } \\
\text { tugas dengan baik. } \\
\text { Penguatkuasaan undang-undang } \\
\text { dilakukan dengan berkesan. }\end{array}$ & & & & & $\begin{array}{l}0.653 \\
0.755 \\
0.692 \\
0.411\end{array}$ \\
\hline $\begin{array}{l}\text { Ganjaran } \\
\text { - } \quad \text { Gaji galak bekerja dengan rajin. }\end{array}$ & & & $\begin{array}{l}0.7 \\
93\end{array}$ & & \\
\hline $\begin{array}{l}\text { Insentif pekerjaan (bonus) galak } \\
\text { melakukan tugas dengan baik. }\end{array}$ & & & $\begin{array}{l}0.7 \\
11\end{array}$ & & \\
\hline $\begin{array}{l}\text { - Penghargaan diberi jika pencapaian } \\
\text { baik. }\end{array}$ & & & $\begin{array}{l}0.6 \\
03\end{array}$ & & \\
\hline $\begin{array}{l}\text { Terima gaji yang setimpal dengan } \\
\text { tugas. }\end{array}$ & & & $\begin{array}{l}0.6 \\
56\end{array}$ & & \\
\hline $\begin{array}{l}\text { Ganjaran (gaji, penghargaan, cuti, } \\
\text { elaun) setimpal dengan usaha }\end{array}$ & & & $\begin{array}{l}0.6 \\
32\end{array}$ & & \\
\hline
\end{tabular}


(sambungan Jadual 3)

\begin{tabular}{|l|c|c|c|c|c|}
\hline Nilai Eigen & 8.57 & 2.08 & 3.66 & 1.82 & 1.30 \\
\hline Varians (\%) & 26.78 & 6.51 & 22.82 & 5.70 & 4.05 \\
\hline Varians Kumulatif (\%) & 26.78 & 33.29 & 22.82 & 18.99 & 28.12 \\
\hline Kaiser-Mayer Olkin (KMO) & 0.89 & & & & \\
\hline
\end{tabular}

keputusan ujian kebolehpercayaan bagi setiap pembolehubah kajian. Nilai alpha bagi pembolehubah latihan dan pembangunan, pembangunan kerjaya, ganjaran, jaminan pekerjaan, dan sokongan pengurusan adalah berada di dalam lingkungan

\begin{tabular}{|c|c|c|c|}
\hline Item & Faktor 1 & Faktor 2 & $\begin{array}{c}\text { Faktor } \\
3\end{array}$ \\
\hline $\begin{array}{l}\text { Nilai Persamaan } \\
\text { - Kagum kejujuran organisasi dalam berurusan dengan pekerja \& } \\
\text { orang awam. } \\
\text { - Berbangga dengan keprihatinan } \\
\text { organisasi terhadap keadaan alam sekitar. } \\
\text { Organisasi menghormati dan melindungi hak dan maruah semua } \\
\text { pekerja. } \\
\text { Organisasi adil dan tidak perlu meminta apa-apa lagi. } \\
\text { Pekerja seharusnya sanggup berkorban apa saja untuk } \\
\text { organisasi. }\end{array}$ & $\begin{array}{l}0.719 \\
0.570 \\
0.769 \\
0.749 \\
0.571\end{array}$ & & \\
\hline $\begin{array}{l}\text { Taat Setia } \\
\text { Kesetiaan yang tinggi kepada kawan-kawan dan keluarga } \\
\text { merupakan kewajipan terpenting bagi setiap individu. } \\
\text { Harus sanggup berkorban untuk kepentingan kawan-kawan dan } \\
\text { keluarga. } \\
\text { Kesetiaan tinggi kepada negara, kewajipan terpenting bagi setiap } \\
\text { individu. }\end{array}$ & & $\begin{array}{l}0.648 \\
0.721 \\
0.713\end{array}$ & \\
\hline
\end{tabular}

\section{Jadual 5}

\section{Keputusan Analisis Ujian Kebolehpercayaan}

\begin{tabular}{lcc}
\hline Faktor & Jumlah item & Nilai alpha \\
\hline Pemboleh Ubah Tidak Bersandar & & \\
$\bullet \quad$ Sokongan Pengurusan & 6 & 0.84 \\
$\bullet$ Jaminan Pekerjaan & 3 & 0.67 \\
$\bullet$ Pembangunan kerjaya & 4 & 0.79 \\
$\bullet$ Latihan dan Pembangunan & 3 & 0.70 \\
- Ganjaran & 5 & 0.77 \\
Pemboleh Ubah Bersandar & & \\
$\bullet$ Kesetiaan kepada Organisasi & 11 & 0.81 \\
- Nilai Persamaan & 5 & 0.78 \\
$\bullet$ Taat Setia & 3 & 0.66 \\
$\bullet$ Dipunyai & 3 & 0.75 \\
\hline
\end{tabular}




\begin{tabular}{|c|c|c|c|}
\hline \multirow[t]{3}{*}{ Jantina } & Lelaki & 301 & 86.2 \\
\hline & Perempuan & 46 & 13.2 \\
\hline & Tidak dinyatakan & 2 & 0.6 \\
\hline \multirow[t]{8}{*}{ Umur } & Di bawah 25 tahun & 126 & 36.1 \\
\hline & 25-29 tahun & 58 & 16.6 \\
\hline & 30-34 tahun & 70 & 20.1 \\
\hline & 35-39 tahun & 73 & 20.9 \\
\hline & 40-44 tahun & 15 & 4.3 \\
\hline & 45-50 tahun & 1 & 0.3 \\
\hline & Lebih dari 50 tahun & 0 & 0.0 \\
\hline & Tidak dinyatakan & 6 & 1.7 \\
\hline Taraf & Bujang & 138 & 39.5 \\
\hline \multirow[t]{3}{*}{ Perkahwinan } & Berkahwin & 208 & 59.6 \\
\hline & Janda/Duda/Balu & 2 & 0.6 \\
\hline & Tidak dinyatakan & 1 & 0.3 \\
\hline \multirow{6}{*}{$\begin{array}{l}\text { Kelayakan } \\
\text { akademik }\end{array}$} & SRP/SPM & 119 & 34.1 \\
\hline & SPM/SPM(V) & 215 & 61.6 \\
\hline & Diploma & 6 & 1.7 \\
\hline & Ijazah Sarjana Muda & 3 & 0.9 \\
\hline & Ijazah Sarjana & 1 & 0.3 \\
\hline & Lain-lain & 5 & 1.4 \\
\hline \multirow{8}{*}{$\begin{array}{l}\text { Tempoh } \\
\text { berkhidmat }\end{array}$} & Kurang daripada 1 tahun & 14 & 4.0 \\
\hline & $1-5$ tahun & 122 & 35.0 \\
\hline & 6-10 tahun & 38 & 10.9 \\
\hline & 11-15 tahun & 98 & 28.1 \\
\hline & 16-20 tahun & 54 & 15.5 \\
\hline & $21-25$ tahun & 15 & 4.3 \\
\hline & Lebih daripada 25 tahun & 1 & 0.3 \\
\hline & Tidak dinyatakan & 7 & 2.0 \\
\hline \multirow[t]{8}{*}{ Gaji } & Kurang daripada RM500 & 33 & 9.5 \\
\hline & RM500-RM1000 & 135 & 38.7 \\
\hline & RM1001-RM1500 & 157 & 45.0 \\
\hline & RM1501-RM2000 & 13 & 3.7 \\
\hline & RM2001-RM2500 & 4 & 1.1 \\
\hline & RM2501-RM3000 & 1 & 0.3 \\
\hline & Lebih daripada RM3000 & 5 & 1.4 \\
\hline & Tidak dinyatakan & 1 & 0.3 \\
\hline
\end{tabular}

\section{Keputusan Analisis Korelasi}

Jadual 7 menunjukkan keputusan analisis korelasi antara pembolehubah tidak bersandar iaitu sokongan pengurusan, pembangunan kerjaya, latihan dan pembangunan, ganjaran, serta jaminan pekerjaan dengan pembolehubah bersandar iaitu kesetiaan, yang terdiri daripada nilai persamaan, taat setia, dan dipunyai. Keputusan menunjukkan wujud hubungan yang signifikan di antara 
0.67 sehingga 0.84. Dapatan ini menunjukkan tahap kebolehpercayaan item ini adalah pada tahap boleh dipercayai. Nilai alpha bagi keseluruhan kesetiaan terhadap organisasi adalah 0.81 manakala bagi nilai persamaan ialah 0.78 , taat setia ialah 0.66, dan dipunyai ialah 0.75. Nilai Alpha Cronbach di antara 0.67 hingga 0.84 menunjukkan ukuran yang digunakan dalam kajian ini mempunyai tahap kebolehpercayaan yang cukup untuk proses penganalisisan data (Nunally, 1978).

\section{LIMITASI KAJIAN}

Kajian ini dijalankan di sebuah organisasi sahaja. Dapatan kajian ini tidak boleh diseluruhkan kepada organisasi yang lain. Selain itu, kajian ini hanya mengkaji dimensi kesetiaan (dipunyai, taat setia, dan nilai persamaan) dan sokongan pengurusan, pembangunan kerjaya, ganjaran, latihan dan pembangunan, serta jaminan pekerjaan. Pengumpulan data dalam kajian ini menggunakan borang soal selidik yang mempunyai skala Likert lima mata. Para responden mungkin mempunyai persepsi dan interpretasi yang berlainan terhadap skala tersebut. Kajian ini juga bersifat keratin rentas. Oleh itu, ia tidak dapat meneliti kesan perubahan dalam pembolehubah-pembolehubah yang telah dikaji.

\section{KEPUTUSAN DAN PERBINCANGAN}

Jadual 6 menunjukkan seramai 301 orang (86.2\%) daripada responden adalah lelaki dan 14 orang (13.2\%) adalah wanita. Berdasarkan umur, seramai 254 orang $(72.8 \%)$ adalah di dalam lingkungan umur 34 dan ke bawah. Seterusnya, seramai 208 orang (59.6\%) daripada responden sudah berkahwin dan 138 orang $(39.5 \%)$ masih belum berkahwin. Hasil kajian ini menunjukkan majoriti daripada responden adalah lelaki yang berumur 34 tahun ke bawah dan sudah berkahwin.

Dari segi tahap kelayakan akademik, seramai 334 orang (95.7\%) mempunyai kelayakan SRP/PMR dan SPM/SPMV. Dari segi tempoh perkhidmatan, 35 peratus daripada responden tersebut telah berkhidmat di antara 1-5 tahun, 28.1 peratus telah berkhidmat selama 11-15 tahun, manakala 15.5 peratus telah berkhidmat selama 16-20 tahun. Dari segi gaji, 45 peratus daripada responden berpendapatan di antara RM1001-RM1500 sebulan. Seramai 38.7 peratus berpendapatan di antara RM500-RM1000 sebulan dan sebanyak 9.5 peratus berpendapatan kurang RM500 sebulan (Jadual 6).

Jadual 6

Taburan Demografi Responden

Demografi Kekerapan Peratus




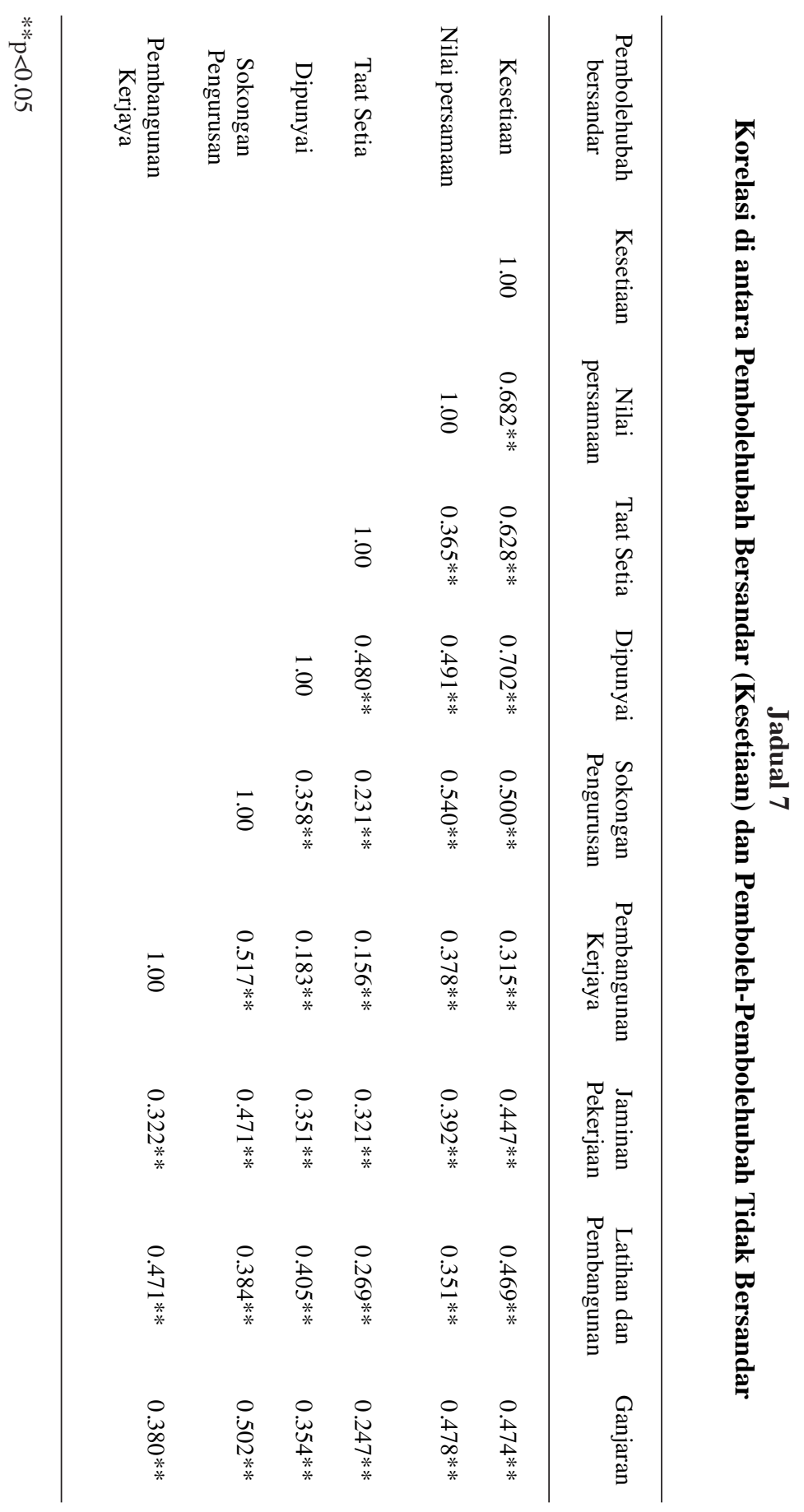


dimensi sokongan pengurusan dengan dimensi kesetiaan dengan nilai pekali korelasi $0.500,(\mathrm{p}<0.05)$. Ini menunjukkan hubungan yang wujud adalah bersifat positif yang sederhana. Dapatan ini juga menunjukkan bahawa sokongan pengurusan mempengaruhi kesetiaan seseorang pekerja terhadap organisasi. Oleh itu, sokongan pengurusan yang baik adalah penting untuk meningkatkan kesetiaan di kalangan pekerja. Hasil kajian juga menunjukkan wujud hubungan di antara dimensi pembangunan kerjaya dengan dimensi kesetiaan dengan nilai pekali korelasi 0.315 , $(\mathrm{p}<0.05)$. Ini menunjukkan terdapat hubungan yang positif, tetapi lemah di antara kedua-dua dimensi. Walau bagaimanapun, hubungan ini menunjukkan dimensi pembangunan kerjaya dapat mempengaruhi tahap kesetiaan seseorang terhadap organisasi.

Hasil kajian juga menunjukkan wujud hubungan yang signifikan di antara dimensi jaminan pekerjaan dengan kesetiaan, dengan nilai pekali korelasi 0.447, ( $\mathrm{p}<0.05)$. Nilai ini menunjukkan hubungan yang wujud adalah positif tetapi lemah. Ini bererti pekerjaan yang stabil dan terjamin akan mempengaruhi seseorang untuk terus setia bekerja dalam organisasi. Selain itu, wujud hubungan positif, tetapi lemah di antara dimensi latihan dan pembangunan dengan dimensi kesetiaan. Ini kerana nilai pekali korelasi bagi kedua-dua dimensi ialah 0.469, $(\mathrm{p}<0.05)$. Dapatan ini menunjukkan program latihan dan pembangunan yang dijalani oleh pekerja memberi kesan terhadap kesetiaan pekerja terhadap organisasi. Keputusan analisis korelasi juga menunjukkan wujud hubungan yang positif, tetapi lemah di antara dimensi ganjaran dengan dimensi kesetiaan, dengan nilai pekali korelasi adalah 0.474 , $(\mathrm{p}<0.05)$. Ini bererti ganjaran yang diterima oleh seseorang pekerja akan mempengaruhi kesetiaan mereka (Jadual 7).

\section{Keputusan Analisis Regresi}

Bahagian ini menerangkan keputusan analisis regresi terhadap pembolehubah bersandar iaitu dimensi kesetiaan yang terbahagi kepada empat, iaitu nilai persamaan, taat setia, dipunyai, dan keseluruhan kesetiaan.

\section{Keputusan Analisis Regresi Terhadap Dimensi Nilai Persamaan}

Jadual 8 menunjukkan keputusan analisis regresi terhadap dimensi nilai persamaan. Keputusan menunjukkan 45.7 peratus daripada varian (R square) bagi dimensi nilai persamaan diterangkan oleh sokongan pengurusan, pembangunan kerjaya, latihan dan pembangunan, ganjaran, dan jaminan pekerjaan. Sokongan pengurusan mempunyai nilai Beta yang tertinggi iaitu 0.193, $(\mathrm{p}<0.05)$, diikuti ganjaran iaitu 0.138, $(\mathrm{p}<0.05)$, dan jaminan pekerjaan iaitu $0.053,(\mathrm{p}<0.05)$. Oleh itu, untuk meningkatkan nilai persamaan, organisasi boleh meningkatkan cara sokongan pengurusan, ganjaran, pembangunan kerjaya, latihan dan pembangunan, serta jaminan pekerjaan dalam organisasi 


\section{Keputusan Analisis Regresi Terhadap Dimensi Dipunyai}

Jadual 10 menunjukkan keputusan analisis regresi pengekalan pekerja terhadap dimensi dipunyai. Keputusan analisis regresi menunjukkan 29.8 peratus daripada varian ( $\mathrm{R}$ square) bagi dipunyai diterangkan oleh pembolehubah sokongan pengurusan, pembangunan kerjaya, latihan dan pembangunan, ganjaran, serta jaminan pekerjaan. Hasil keputusan menunjukkan semua pembolehubah bebas mempunyai perkaitan yang signifikan dengan dimensi dipunyai $(p<0.05)$. Dimensi tersebut ialah sokongan pengurusan, jaminan pekerjaan, pembangunan kerjaya, latihan dan pembangunan, serta ganjaran. Daripada lima dimensi ini, dimensi latihan menunjukkan nilai Beta yang tertinggi iaitu 0.265, $(\mathrm{p}<0.05)$ yang menerangkan program latihan dan pembangunan yang baik akan dapat meningkatkan tahap rasa dipunyai di kalangan pekerja terhadap organisasi. Nilai ini diikuti dengan sokongan pengurusan iaitu 0.148, $(\mathrm{p}<0.05)$ dan jaminan pekerjaan iaitu $0.138,(\mathrm{p}<0.05)$. Walau bagaimanapun, dimensi pembangunan kerjaya menunjukkan perkaitan yang wujud adalah bersifat negatif iaitu nilai Beta adalah $-0.170,(\mathrm{p}<0.05)$. Oleh itu, peningkatan dalam program latihan dan pembangunan serta jaminan pekerjaan mampu untuk meningkatkan rasa dipunyai oleh seseorang pekerja terhadap organisasi.

\section{Jadual 10}

\section{Keputusan Analisis Regresi terhadap Dimensi Dipunyai}

$\begin{array}{lccc}\text { Dimensi } & \text { B } & \text { Beta } & \text { t value } \\ & & & \\ \text { (Constant) } & 1.368 & & 4.001 \\ \text { Sokongan Pengurusan } & 0.153 & 0.148 & 2.297^{* *} \\ \text { Jaminan Pekerjaan } & 0.143 & 0.138 & 2.470^{* *} \\ \text { Pembangunan Kerjaya } & -0.145 & -0.170 & -2.803^{* *} \\ \text { Latihan dan Pembangunan } & 0.280 & 0.265 & 4.704^{* *} \\ \text { Ganjaran } & 0.129 & 0.141 & 2.392^{* *} \\ & & & \\ \text { p }<0.05 \quad \text { R square }=0.298 & & & \end{array}$

\section{Keputusan Analisis Regresi Terhadap Keseluruhan Kesetiaan}

Jadual 11 menunjukkan keputusan analisis regresi pengekalan pekerja terhadap dimrensi keseturuhran kesetraanr. Keputusanा menाunjukkanा 47 peratus daripada varian (R square) bagi keseluruhan kesetiaan diterangkan oleh dimensi sokongan pengurusan, pembangunan kerjaya, latihan dan pembangunan, ganjaran, serta jaminan pekerjaan. Hanya dimensi sokongan pengurusan, jaminan pekerjaan, $\underline{\text { serta latihan dan pembangunan, mempunyai hubungan yang signifikan dengan }}$ 
(sambungan Jadual 9)

tersebut.

\section{Jadual 8}

Keputusan Analisis Regresi terhadap Dimensi Nilai Persamaan

\begin{tabular}{lccc}
\hline Dimensi & B & Beta & t value \\
& & & \\
(Constant) & 0.313 & & 1.017 \\
Sokongan Pengurusan & 0.203 & 0.193 & $3.391^{* *}$ \\
Jaminan Pekerjaan & $5.646 \mathrm{E}-02$ & 0.053 & 1.081 \\
Pembangunan Kerjaya & $2.890 \mathrm{E}-03$ & 0.003 & 0.062 \\
Latihan dan Pembangunan & $4.875 \mathrm{E}-02$ & 0.045 & 0.908 \\
Ganjaran & 0.130 & 0.138 & $2.665^{* *}$ \\
$*$ * & & & \\
& & &
\end{tabular}

\section{Keputusan Analisis Regresi Terhadap Dimensi Taat Setia}

Jadual 9 menunjukkan keputusan analisis regresi pengekalan pekerja terhadap dimensi taat setia. Keputusan analisis regresi menunjukkan 19.8 peratus daripada varian ( $\mathrm{R}$ square) bagi dimensi taat setia diterangkan oleh pembolehubah sokongan pengurusan, pembangunan kerjaya, latihan dan pembangunan, ganjaran, serta jaminan pekerjaan. Hasil daripada keputusan tersebut memaparkan hanya jaminan pekerjaan, mempunyai hubungan yang signifikan dengan dimensi taat setia $(\mathrm{p}<0.05)$. Nilai Beta 0.195, $(\mathrm{p}<0.05)$ bagi jaminan pekerjaan merupakan dimensi yang mempunyai perkaitan yang terpenting untuk menerangkan tahap taat setia seseorang.

Jadual 9

Keputusan Analisis Regresi terhadap Dimensi Taat Setia

\begin{tabular}{lccc}
\hline Dimensi & $\mathrm{B}$ & Beta & $\mathrm{t}$ value \\
\hline (Constant) & 2.294 & & 7.125 \\
Sokongan Pengurusan & $2.804 \mathrm{E}-02$ & 0.031 & 0.448 \\
Dimensi & $\mathrm{B}$ & $\mathrm{Beta}$ & $\mathrm{t}$ value \\
& & & \\
Jaminan Pekerjaan & 0.178 & 0.195 & $3.260 * *$ \\
Pembangunan Kerjaya & $-5.185 \mathrm{E}-02$ & -0.069 & -1.065 \\
LatihrandanPembanguman & 0.107 & 0.115 & 1.913
\end{tabular}

$* * \mathrm{p}<0.05 \quad \mathrm{R}$ square $=0.198$ 
Hasil analisis korelasi dan regresi juga mendapati ganjaran adalah faktor yang menyumbang kepada tahap kesetiaan di kalangan pekerja. Dapatan ini selari dengan tujuan utama pemberian ganjaran iaitu untuk mengekal, memotivasi, dan meningkatkan kesetiaan pekerja. Penemuan ini sama dengan dapatan Chiu et al. (2002) yang menyatakan bahawa ganjaran adalah penting untuk mengekalkan pekerja. Walau bagaimanapun, Carciner et al. (2004) mendapati ganjaran tidak mempengaruhi kesetiaan terhadap organisasi. Secara umumnya, faktor yang mempengaruhi kesetiaan terhadap organisasi ini adalah selari dengan faktor yang diketengahkan oleh Trott (1996), Milliman et al. (2003), serta Mathis dan Jackson (2004).

\section{KESIMPULAN}

Sokongan pengurusan yang baik dapat meningkatkan kesetiaan pekerja terhadap organisasi. Oleh itu, penghargaan dan sikap ambil berat oleh pihak pengurusan dan organisasi terhadap pekerja adalah sangat penting. Begitu juga dengan aspek pembangunan kerjaya, jika pekerja diberi maklumat yang lengkap dan jelas tentang peluang pembangunan kerjaya, mereka akan lebih berminat untuk terus kekal bekerja dalam organisasi tersebut. Jelas sekali bahawa ketelusan daripada pihak majikan memberi maklumat tentang pembangunan kerjaya penting dalam meningkatkan kesetiaan pekerja. Aspek latihan dan pembangunan juga penting kerana pekerja akan terus setia dengan sesebuah organisasi yang memberi mereka peluang untuk menambahkan pengetahuan, kemahiran dan kebolehan lain melalui program latihan dan pembangunan yang disediakan oleh pihak pengurusan. Jaminan pekerjaan ialah pekerjaan yang stabil tanpa mengalami sebarang kesulitan dan pemberhentian turut mempengaruhi tahap kesetiaan pekerja. Oleh itu, adalah menjadi tanggungjawab majikan mewujudkan keadaan pekerjaan yang stabil dan terjamin agar pekerja terus setia terhadap organisasi. Selain itu, ganjaran seperti pemberian gaji, ganjaran, dan penghargaan yang memuaskan serta setimpal dengan tugas yang dilakukan dapat membantu organisasi meningkatkan kesetiaan pekerja.

Secara keseluruhannya, hasil kajian mendapati tahap kesetiaan terhadap organisasi di kalangan pekerja di sektor awam adalah dipengaruhi oleh sokongan pengurusan, pembangunan kerjaya, jaminan pekerjaan, dan ganjaran. Oleh itu, adalah penting bagi pihak majikan mengambilkira faktor-faktor tersebut dalam meningkatkan kesetiaan di kalangan pekerja dalam sesebuah organisasi.

\section{RUJUKAN}

Acton, T. \& Golden, W. 2003. Training the Knowledge Worker: A Descriptive Study of Training Practices in Irish Software Companies. Journal of 
dimensi keseluruhan kesetiaan $(\mathrm{p}<0.05)$. Dimensi latihan dan pembangunan menunjukkan nilai Beta yang tertinggi iaitu 0.171, diikuti dengan dimensi sokongan pengurusan iaitu $0.159,(\mathrm{p}<0.05)$, dan jaminan pekerjaan 0.143 , $(\mathrm{p}<0.05)$.

Dapatan ini menunjukkan untuk meningkatkan tahap keseluruhan kesetiaan, perancangan program latihan yang baik perlu dititikberatkan, selain melakukan peningkatan kepada sokongan pengurusan dan jaminan pekerjaan. Apabila tahap keseluruhan kesetiaan meningkat, keinginan untuk meninggalkan organisasi akan kurang. Justeru itu, boleh disimpulkan bahawa program latihan, sokongan pengurusan, dan jaminan pekerjaan merupakan faktor yang mempengaruhi kesetiaan pekerja terhadap organisasi.

\section{Jadual 11 \\ Keputusan Analisis Regresi Pengekalan Pekerja terhadap Dimensi Keseluruhan Kesetiaan}

$\begin{array}{lccc}\text { Dimensi } & \text { B } & \text { Beta } & \text { T value } \\ \text { (Constant) } & 1.015 & & \\ \text { Sokongan Pengurusan } & 0.128 & 0.159 & 2.212 \\ \text { Jaminan Pekerjaan } & 0.117 & 0.143 & 2.948^{* *} \\ \text { Pembangunan Kerjaya } & -7.074 \mathrm{E}-02 & -0.106 & -2.039 \\ \text { Latihan dan Pembangunan } & 0.150 & .171 & 3.288^{* *} \\ \text { Ganjaran } & -1.750 \mathrm{E}-02 & .130 & 2.507\end{array}$

$* * \mathrm{p}<0.05 \quad \mathrm{R}-$ Square $=0.470$

Hasil kajian menunjukkan faktor sokongan pengurusan mempengaruhi kesetiaan pekerja terhadap organisasi. Ini adalah kerana sokongan pengurusan yang mantap dari segi fizikal dan emosi dapat mewujudkan budaya kerja yang lebih baik dalam sesebuah organisasi. Pekerja memerlukan sokongan dari aspek fizikal dan emosi. Dapatan ini selari dengan kajian Firth et al. (2004) yang menyatakan kesetiaan terhadap organisasi dapat ditingkatkan jika pengurusan/penyelia memberi sokongan kepada pekerja. Analisis korelasi dan regresi juga menunjukkan bahawa jaminan pekerjaan mempengaruhi kesetiaan pekerja terhadap organisasi. Pekerja kurang tahap kesetiaan jika pekerjaan tersebut tidak mempunyai jaminan. Kajian Bishop et al. (2002) juga mendapati pekerjaan yang stabil dapat meningkatkan komitmen dan kesetiaan. Berdasarkan analisis korelasi dan regresi, latihan dan pembangunan juga adalah faktor yang mempengaruhi tahap kesetiaan pekerja. Dapatan kajian ini tidak sama dengan kajian oleh Acton dan Golden (2003) yang mendapati latihan tidak mempengaruhi kesetiaan terhadap organisasi. 
Model:Replication and Extension. Human Relations. 52: 383-416.

Kim, S. W., Price, J. L., Mueller, C. W. \& Watson, T. W. 1996. The Determinants of Career Intent Among Physicians at a US Air Force Hospital. Human Relations. 49: 947-976.

King, A. S.\& Ehrhard B. H. 1997. Empowering the Workplace: A Commitment Cohesion Exercise. Empowerment in Organizations. 5:139-150.

Lam, T. \& Qiu Zhang, H. 2003. Job Satisfaction and Organizational Commitment in the Hong Kong Fast Food Industry. International Journal of Contemporary Hospitality Management. 15:214-220.

Leana, C. R. \& Feldman, D. C. 1992. Coping With Job Loss: How Individuals, Organizations, and Communities Respond To Layoffs. New York: Lexington Books.

Luis Carciner, M. P., Sanchez, A. M., Perez, M. P., \& Vela Jiminez, M. J. 2004. Analysis of Internal and External Labor Mobility: A Model of JobRelated and Non-Related Factors. Personnel Review. 33(2): 222-240.

Maslyn, J. M. \& Fedor, D. B. 1998. Perceptions of Politics: Does Measuring Different Foci Matter? Journal of Applied Psychology. 84: 645-653.

Mathis, R. L. \& Jackson, J. H. 2004. Human Resource Management. $10^{\text {th }}$ Ed. Singapore: South-Western

Meltz, N. M. 1989. Job Security in Canada. Industrial Relations. 44:149-160.

Milliman, J., Czaplewski, A. J., \& Ferguson, J. 2003. Workplace Spirituality and Employee Work Attitudes: An Exploratory Empirical Assessment. Journal of Organizational Change Management. 16(4): 426-447.

Milkovich, G. \& Newman, J. 2002. Compensation Administration. Homewood: Irwin.

Mondy, R. W. \& Noe, R. M. 2001. Human Resource Management. $9^{\text {th }}$ Ed. New Jersey: Pearson Prentice Hall.

Nunally, J. C. 1978. Psychometric Theory. New York: McGraw Hill.

Parker, C.P., Dipboye, R. L. \& Jackson, S. L. 1995. Perceptions of Organizational Politics: An Investigation of Antecedents and Consequences. Journal of Management. 21: 891-912.

Poon, M. L. 2003. Situational Antecedents and Outcomes of Organizational Politics Perceptions. Journal of Managerial Psychology. 18(2): 138-155.

Price, J. P. 2001. Reflections on the Determinants of Voluntary Turnover. International Journal of Manpower. 22(7): 600-624.

Robbins, S. P. 2001. Strategic Human Resource Management: Linking the People with the Strategic Needs of the Business. Organizational Dynamic. Summer: 18-32.

Solomon, C. 1998, "Building teams across borders", Global Workforce, 3 (6), pp. $62-81$.

Trott, D. C. 1996. Spiritual Well-Being of Workers: An Exploratory Study of Spirituality in the Workplace, University of Texas, Austin, TX.

Sekaran, U. 2003. Research Methods for Business: A Skill Building Approach. New York: John Wiley \& Sons, Inc. 
European Industrial Training. 27: 137-146.

Becker, T. E., Billings, D. M., dan Gilber, N. L. 1996. Foci and Bases of Employee Commitment: Implications of Job Performance. Academy of Management Journal. 39: 464-482.

Bishop, J. W., Goldsby, M. G., \& Neck, C. P. 2002. Who Goes? Who Cares? Who Stays? Who Wants To? The Role of Contingent Workers and Corporate layoff Practices. Journal of Managerial Psychology. 17: 298-315

Burke, R. J. 1997. Correlates of Job in Security Among Recent Business School Graduates. Employee Relation. 20:92-98.

Chen, Z. 2001. Further Investigation of the Outcomes of Loyalty to Supervisor: Job Satisfaction and Intention to Stay. Journal of Managerial Psychology. 16 (8): 650-660.

Chiu, R. K. \& Francesco, A. M. 2003. Dispositional Traits and Turnover Intention: Examining the Mediating Role of Job Satisfaction and Affective Commitment. International Journal of Manpower. 24(3): 284-298.

Cropanzano, R., Howes, J. C., Grandey, A. A. \& Toth, P. 1997. The Relationship of Organizational Politics and Support to Work Behaviors, Attitudes, and Stress. Journal of Organizational Behavior. 18:158-180.

Desimone, R. L., Werner, J. M. \& Harris, D. M. 2002. Human Resource Development. Orlando, FL: Harcourt Inc.

Ferris, G. R., Frink, D. D., Galang, M. C., Zhou, J., Kacmar, K. M. \& Howard J. L. 1996. Perceptions of Organizational Politics: Prediction, StressRelated Implications, and Outcomes. Human Relations. 49: 233-266.

Firth L., Mellor, D. J., Moore, K.A., \& Loquet, C. 2004. How Can Managers Reduce Employee Intention to Quit? Journal of Managerial Psychology. 19 (2): 170-187.

Gregersen, H. B. 1993. Multiple Commitments at Work and Extra Role Behavior during Three Key Mediating Construct. Academy of Management Journal. 33: 568-1587.

Hansemark, O. C. \& Albinson, M. 2004. Customer Satisfaction and Retention: The Experiences of Individual Employees. Managing Service Quality. 14(1): 40-57.

Harris, S. G., Hirshfeld, R. R., Field, H. S. \& Mossholder, K. W. 1993. Psychological Attachment: Relationship With Job Characteristics, Attitudes, and Preferences for Newcomer Development. Group and Organization Management. 18:459- 481.

Henderson, R. I. 2000. Compensation Management in a Knowledge-Based World. $8^{\text {th }}$ ed. Upper Saddle River: Prentice-Hall.

Isen, A. M. \& Baron, R. A. 1991. Positive Affect as a Factor in Organizational Behavior. Research in Organizational Behavior. 13: 1-53.

Kacmar, K. M., Bozeman, D. P., Carlson, D. S. \& Anthony, W. P. 1999. An Examination of the Perceptions of Organizational Politics 
Yousef, D. A. 1998. Satisfaction with Job Security as a Predictor of Organizational Commitment and Job Performance in a Multicultural Environment. International Journal of Manpower. 19: 188-194.

Khulida Kirana Yahya, Ph.D

Profesor Madya

Johanim Johari

Zurina Adnan

Mohd Faizal Mohd Isa

Zulkiflee Daud

Fakulti Pembangunan Sosial dan Manusia

06010 Universiti Utara Malaysia

Sintok, Kedah Darul Aman, Malaysia 